\title{
Population status of endemic tree kokoleceran (Vatica bantamensis) in Ujung Kulon National Park, Indonesia
}

\author{
IYAN ROBIANSYAH ${ }^{1, \boldsymbol{v}}$, DODO $^{1}$, ARIEF HAMIDI ${ }^{2}$ \\ ${ }^{1}$ Center for Plant Conservation-Bogor Botanical Gardens, Indonesian Institute of Sciences. Jl. Ir. H. Djuanda No. 13, Paledang, Bogor 16122, West Java, \\ Indonesia. Tel. +62-251-8322187, Fax.+62-251-8322187, `email: iyan.robiansyah@lipi.go.id, iyanrobiansyah @yahoo.com \\ ${ }^{2}$ Fauna \& Flora International-Indonesia Program. Jl. Margasatwa Baru Blok A No.6 Jakarta 12450, Indonesia
}

Manuscript received: 19 March 2018. Revision accepted: 31 December 2018.

\begin{abstract}
Robiansyah I, Dodo, Hamidi A. 2019. Population status of endemic tree kokoleceran (Vatica bantamensis) in Ujung Kulon National Park, Indonesia. Biodiversitas 20: 296-302. Kokoleceran (Vatica bantamensis) is an endemic tree found only in Ujung Kulon National Park (UKNP), Banten, Indonesia, and is classified as Endangered by IUCN Red List. To develop effective conservation measures of threatened plants, current information on population status and distribution of the species is needed. Thus in the present study, a targeted survey of kokoleceran was conducted in UKNP aiming at mapping the distribution of the species, measuring current population size and structure, assessing the habitat preferences, and identifying threats to the species. Using a non-random adaptive cluster sampling, a total of 27 clusters harboring 280 individuals of kokoleceran was located, of which $20 \%$ were in mature stage. All these individuals were only found in Mount Payung and its surrounding areas, and formed an inverse-J-shaped population structure pattern. The species was estimated to have an area of occupancy and extent of occurrence of $8 \mathrm{~km}^{2}$. The invasive langkap palm (Arenga obtusifolia, Arecaceae) was identified as the main threat for kokoleceran. Based on these results, kokoleceran appears to more than justify its conservation status of Critically Endangered B1ab(iii,v) +2ab(iii,v); C2a(ii).
\end{abstract}

Keywords: Dipterocarpaceae, endemic, kokoleceran, Ujung Kulon National Park, Vatica bantamensis

\section{INTRODUCTION}

Indonesia is a large archipelago nation with more than 14.700 islands, and is one of the most biodiverse countries in the world. In spite of having the fourth largest population in the world, its forest cover is the highest in the world after the Amazon (FFI 2018). Indonesia harbors 42.584 plant species, of which $39 \%$ are endemic i.e. exist nowhere else on earth (Widjaja et al. 2014). This high flora diversity, however, is facing serious threats from habitat loss and degradation, overexploitation, pollution, invasive alien species, and climate change.

Kokoleceran (Vatica bantamensis) is one of Indonesian endemic tree found only in Ujung Kulon National Park (UKNP), western Java, and is classified as Endangered by IUCN Red List (Ashton 1998). The key threats to $V$. bantamensis, and the national park as a whole, are illegal logging and habitat loss due to agricultural encroachment and firewood collection (http://whc.unesco.org/en/list/608). Furthermore, the massive distribution of invasive langkap palm (Arenga obtusifolia) is also known to have negative effects on the flora diversity of UKNP, including kokoleceran (Haryanto 1999; Evnike 2013). Although it is a native species, langkap palm can dominate the landscape and suppress the growth of other species seedling through light lessening mechanism (Prayitno 1995). The Invasive Species Specialist Group of the IUCN Species Survival Commission has included langkap in its Global Invasive Species Database (http://www.issg.org/database). Muntasib and Haryanto (1992) reported that the invasiveness of langkap is caused by its advantageous biological properties, especially: i) rapid recuperation capacity after destruction of the above-ground parts, ii) ability to produce many seeds; one tree can produce 945-5400 seeds per fruiting spadix, iii) ability to defend against herbivores by means of high concentration of oxalate compounds in its immature seeds.

As an endemic plant species with very narrow geographic ranges, kokoleceran has a small population number. The last survey conducted in 2010 found only 4 mature trees of the species, which concentrated at a single location in the national park (Wihermanto et al. 2015). This low population number makes the species very vulnerable to extinction under demographic and environmental stochastic effects. In addition, species with small population size and a restricted geographic range is expected to have reduced level of genetic diversity. This insufficient variability will lead the species to be more vulnerable under new selection pressure.

To develop effective conservation measures, current information on population size and distribution of the species is needed. Thus in the present study, a targeted survey of kokoleceran in UKNP will be conducted thoroughly. The aims are to: (i) map the distribution of the species in UKNP, (ii) measure current population size and structure of the species, (iii) assess habitat preferences of kokoleceran, and (iv) identify current threats and disturbances to the species. The study will provide the most current status of kokoleceran in UKNP that might assist comprehensive conservation measures of the species and 
its habitat. It could also be used as baseline data for periodic population monitoring of the species in the future.

\section{MATERIAL AND METHODS}

\section{Study site}

Ujung Kulon National Park (UKNP) is located at the western most tip of Java Island, within Banten Province of Indonesia $\left(6^{\prime} 45^{\circ} \mathrm{S}, 105^{\prime} 20^{\circ} \mathrm{E}\right)$. UKNP was designated as a world heritage site by UNESCO in 1991 (http://whc.unesco.org/en/list/608) due to its natural beauty, geological uniqueness and high diversity of plant and animal species. Covering an area of 78,525 ha, the park contains the largest remaining area of lowland rainforests in the Java Island which harbors several endangered plants, including the endemic Heritiera percoriacea Kosterm. (Malvaceae) and Vatica bantamensis (Hassk.) Benth. \& Hook.ex Miq. (Dipterocarpaceae).

The study was conducted in Mount Payung of UKNP, the only place where the target species of $V$. bantamensis (kokoleceran) was found (Figure 1). Mostly surrounded by seas, climate conditions of UKNP are tropical maritime. The climate is categorized in type A (Hommel 1987), with mean temperatures ranges between $25^{\circ} \mathrm{C}$ and $30^{\circ} \mathrm{C}$ and relative humidity ranges between $80 \%$ and $90 \%$ (Clarbrough 1999; Dephut 2007). Mean annual rainfall is ca. 3,250 mm, with the respective heaviest rainfall and drier period occurring from October to April and from May to September following annual north-west and south-east monsoon cycles (Rahman et al. 2017).

\section{Study species}

Kokoleceran (Vatica bantamensis (Hassk.) Benth. \& Hook.ex Miq.) belongs to Dipterocarpaceae family. Endemic to Mount Payung of UKNP, the tree was under endangered category of IUCN Red List since 20 years ago (Ashton 1998). It is medium-sized tree which can grow up to $30 \mathrm{~m}$ height (Figure 2). The young parts were covered by soft hair. Leaves are elliptic or lanceolate with lamina size of (4.5-)7.5-18 by (1.8-)3.5-7.5 $\mathrm{cm}$ and number of secondary vein of $9-11$ pairs. The fruit was up to $10 \mathrm{~cm}$ in length with 5 wings, 2 of which are longer than the others. The seeds are round in shape with diameter of $1 \mathrm{~cm}$. The tree is closely related to Vatica rassak (Korth.) Blume (Kalima and Wardani 2017).

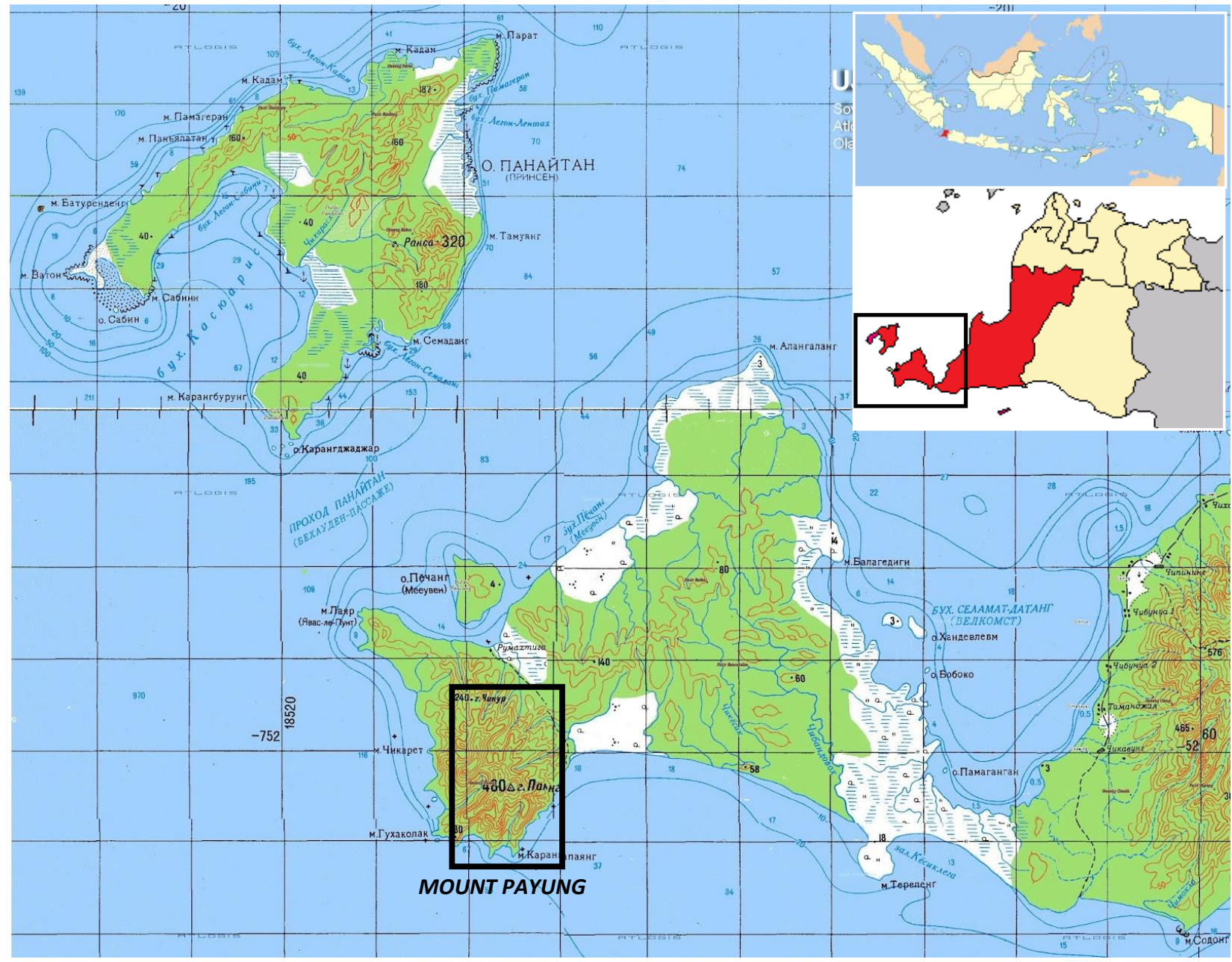

Figure 1. Location of Mount Payung in Ujung Kulon National Park, Banten, Indonesia 


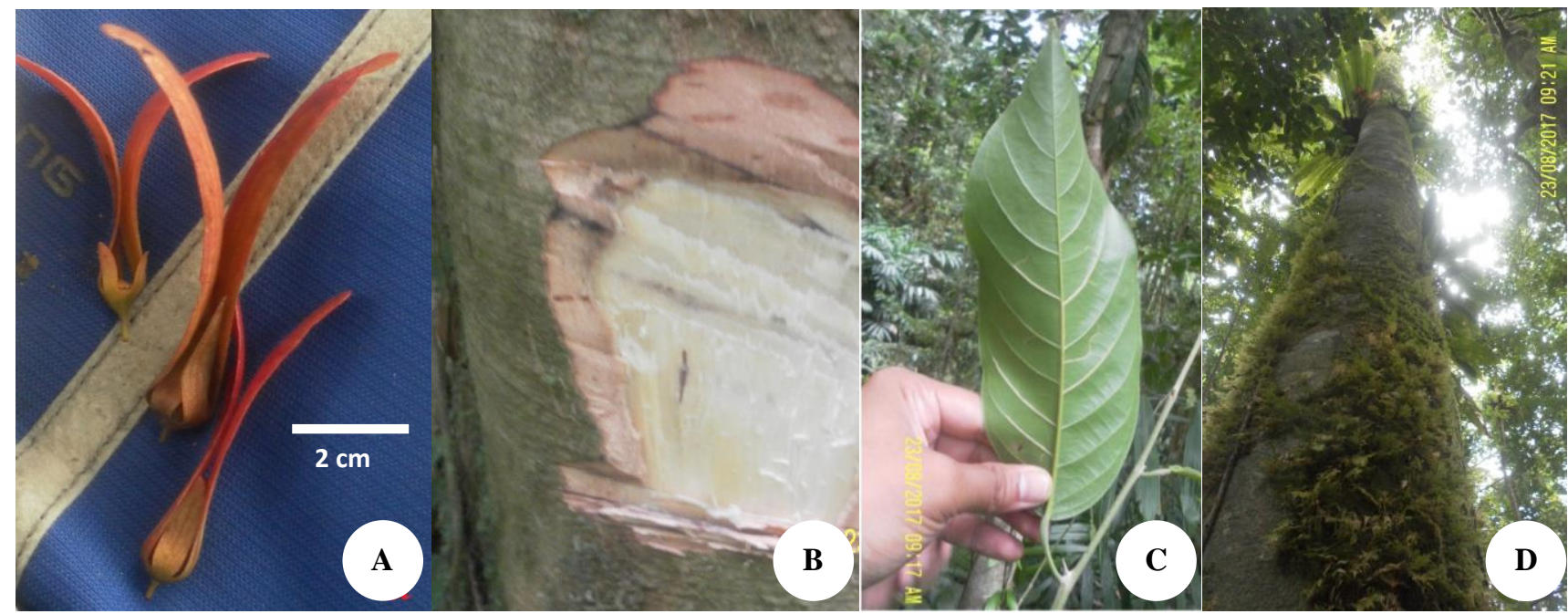

Figure 2. Morphological features of kokoleceran (Vatica bantamensis): A. Fruits, B. Bark, C. Leaves, D. Trunk

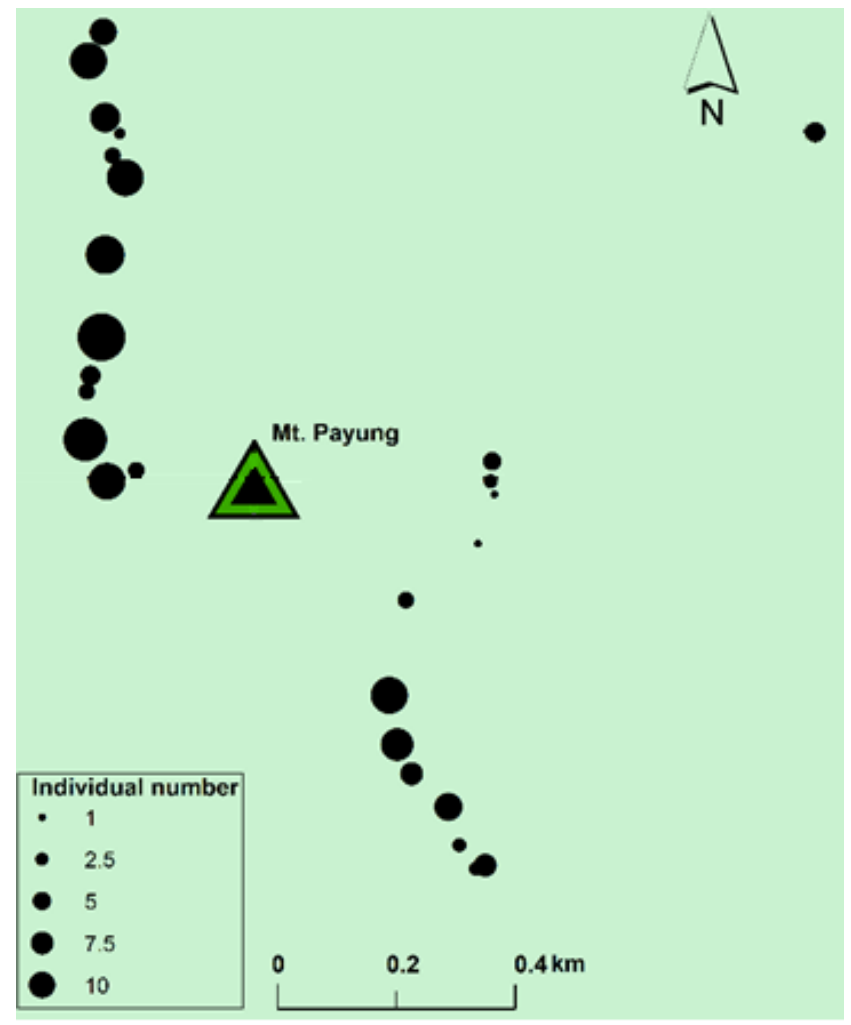

Figure 3. Distribution of kokoleceran (Vatica bantamensis) in Mount Payung, Ujung Kulon National Park, Banten, Indonesia

\section{Population and habitat assessment}

The survey was conducted on August 2017 in Mount Payung of UKNP. To assess the distribution and population size of kokoleceran, a non-random adaptive cluster sampling was employed. The sampling was started from the base camp by walking around the forest to search for the species. This search was conducted for four days and covered a total distance of c. $4 \mathrm{~km}$. Where the tree was located, individual counting and diameter at breast height (dbh) measurement of kokoleceran with height $\geq 1.3 \mathrm{~m}$ was carried out within $10 \times 10 \mathrm{~m}$ quadrat. The neighboring areas of this quadrat were then observed for the presence of the target species. If at least one individual of kokoleceran was detected, a neighboring 10x10 m quadrat was added to the initial quadrat. Quadrats were added repeatedly until no additional plots containing kokoleceran anymore. The sampling was then started again in a different area of the forest where the target species was found. Individual with flowers or fruits was recorded and assigned as mature. The following environmental variables were measured at the center of each cluster: topography (ridge, slope or valley), altitude, slope, aspect, soil properties (texture, organic carbon, total nitrogen, humidity, and $\mathrm{pH}$ ), canopy coverage of trees and habitat disturbances.

\section{Data analysis}

Habitat preferences of kokoleceran were descriptively described based on collected environmental data. Factors influencing the density of the species were assessed using a general linear model (GLM) with all categorical variables were included as fixed factors. To estimate the extent of occurrence (EOO) and area of occupancy (AOO) of the species, all GPS locations for quadrats containing the species were input at GeoCAT (Geospatial Conservation Assessment Tool) (Bachman and Moat 2012; http://geocat.kew.org). All the results obtained by the present study were used as the basis for assessing the conservation status of kokoleceran against all criterion set by IUCN Red List (IUCN 2012).

\section{RESULTS AND DISCUSSION}

\section{Spatial distribution, population size, and structure}

A total of 27 clusters harboring 280 individuals of kokoleceran was found in Mount Payung during the survey. The clusters could be consisted of 1 to 6 plots and contain up to 34 individuals/cluster. All these individuals were located in Mount Payung and its surrounding areas (Figure 3). 


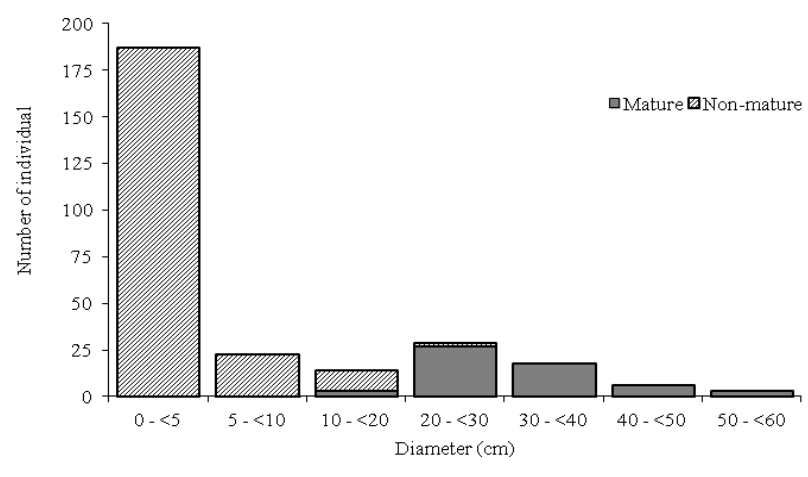

Figure 4. Population structure of kokoleceran (Vatica bantamensis) in Mount Payung, Ujung Kulon National Park, Banten, Indonesia

Clumped spatial distribution of kokoleceran was also commonly found on other tropical trees (Ashton 1969; Condit et al. 2000; Fangliang et al. 1997; Richards 1996), which most likely due to poor dispersal of propagules (Bunyavejchewin et al. 2003). This pattern leads to highly concentrated seed and seedling directly below the mother tree and decreases with increasing distance from the mother tree. It seems that having highly clumped population was one-way kokoleceran could survive. In other dipterocarp species, clumping distribution might ensure effective pollination between individuals (Hubbell 1979), avoid seed predation through mass flowering and fruiting (Janzen 1974), or increase the probability that a viable seed will fall in a habitat with suitable mycorrhizal inoculum (Ashton 1982; Smits 1982).

Population structure of kokoleceran, as represented by dbh classes, showed an inverse-J-shaped pattern (Figure 4). The younger trees dominated the population as indicated by a very high number of individuals in the $0-<5 \mathrm{~cm}$ class $(66.8 \%)$. This type of population structure pattern is common for most dipterocarp species (Fox 1973), and is also similar to of another Java Island endemic tree Dipterocarpus littoralis (Robiansyah and Davy 2015). Inverse-J demography, with continuous recruitment, is often regarded as indication of a stable or expanding population. In addition, more than $20 \%$ (58 individuals) of located trees were in mature stage, i.e., producing flower and fruits (Figure 4). The smallest mature tree found to be producing flower was with $\mathrm{dbh}$ of $8 \mathrm{~cm}$. The number of mature individuals found by our study was considerably higher compared to 4 individuals of mature tree found by the previous study.

\section{Habitat preferences}

The species was only found above the elevation of 400 $\mathrm{m}$ asl (Table 1). Two possible causes might underlie this restricted elevation range: dominant distribution of langkap tree on the lower elevation which prevents kokoleceran to grow, or this elevation range was the optimum condition for kokoleceran to grow which may relate to optimum temperature, humidity, soil composition, and solar radiation for the tree. Further investigations are required to see which factor affects the elevation range of the species.
Locations with dense canopy cover and acidic soil were likely to be good habitat for the tree (Table 1). As the early stage individuals $(\mathrm{dbh} 0-5 \mathrm{~cm})$ dominated the population, this preference of dense canopy cover might indicate that kokoleceran was shade-tolerant/demanding species during its early development. Lemmens et al. (2017) indeed stated that seedling of Vatica spp. need shade for its optimal growth and development. For acidic soil, it was commonly found in the soil of dipterocarp forests. Soil $\mathrm{pH}$ of $D$. littoralis habitat in Nusakambangan Island, for instance, was 4.2 to 6 (Robiansyah and Davy 2015), whereas dipterocarp forest of Bukit Timah Nature Reserve in Singapore had a soil $\mathrm{pH}$ of 3.5-4.2 (Turner 2012). In general, most lowlands mixed dipterocarp forest soils were reported as having topsoil $\mathrm{pH}$ in the range 4.0-4.5 (Grubb et al. 1994).

The occurrence of kokoleceran had no preferences in term of aspect (Table 2). For topographic position, kokoleceran could be regarded as slope and ridge specialist as all individuals were located at these two topographic features, while none of them were found at valleys (Table 2). Ghazoul (2016) stated topographic position is strongly associated with several factors important for plant survival, such as water availability, sun exposure, soil and nutrient content, and disturbance regimes (e.g., wind and landslide). Regarding kokoleceran, further study is needed to elucidate which of these factors that are associated with topographic position at Mount Payung, which drives the tree to become slope and ridge specialist.

Table 1. Microhabitat characteristics of kokoleceran (Vatica bantamensis) in Mount Payung, Ujung Kulon National Park, Banten, Indonesia $(n=20)$

\begin{tabular}{lllll}
\hline & Min. & Max. & Mean & SD \\
\hline Elevation & 413 & 505 & 463.10 & 25.96 \\
Slope & 9.8 & 43.4 & 27.27 & 8.83 \\
Canopy gap & 7.36 & 21.76 & 13.44 & 3.24 \\
Soil & & & & \\
pH & 4.5 & 5.14 & 4.83 & 0.17 \\
Organic carbon (\%) & 1.49 & 9.65 & 5.64 & 1.90 \\
$\quad$ Total Nitrogen (\%) & 0.13 & 0.51 & 0.37 & 0.10 \\
$\quad$ Water content $(\%)$ & 0.24 & 34.93 & 17.54 & 9.36 \\
\hline
\end{tabular}

Table 2. Aspect and topography preferences of kokoleceran (Vatica bantamensis) in Mount Payung, Ujung Kulon National Park, Banten, Indonesia

\begin{tabular}{lll}
\hline & Frequency & Percent \\
\hline Aspect & 2 & \\
North & 1 & 10 \\
Northeast & 2 & 5 \\
East & 4 & 10 \\
Southeast & 1 & 20 \\
South & 1 & 5 \\
South west & 7 & 5 \\
West & 2 & 35 \\
Northwest & & 10 \\
Topography & 7 & \\
Ridge & 13 & 35 \\
Slope & & 65 \\
\hline
\end{tabular}


GLM results (Table 3) revealed that kokoleceran density was significantly influenced by elevation, north and east aspect, soil nitrogen content, soil $\mathrm{pH}$ and soil water content $(\mathrm{df}=11, \mathrm{~F}=3.6, p=0.04)$. The higher density of kokoleceran was likely to occur at north-facing slope. This was possibly related to less strong wind disturbance that came from the Indian Ocean. Furthermore, the tree was also predicted to have higher density at lower elevation of its elevation range, more acidic soil, lower soil nitrogen content, and wet soil. Similar pattern of positive association between stem density and lower elevation was also observed for Hopea odorata in the Huai Kha Khaeng Wildlife Sanctuary, Thailand (Bunyavejchewin et al. 2003). Interpreting this pattern, however, requires caution as topographic features (e.g. elevation and aspect) were usually associated with edaphic factors (Ghazoul 2016), including other previously mentioned significant factors influencing kokoleceran, i.e. $\mathrm{pH}$, nutrient content, and water availability. Thus, controlled experiment is needed in which the variable in question can be tested in isolation from other factors.

Table 3. General linear model (GLM) results of factors significantly affecting the density of kokoleceran (Vatica bantamensis) in Mount Payung, Ujung Kulon Nationa Park, Banten, Indonesia

\begin{tabular}{lllll}
\hline Source & B & df & F & $\boldsymbol{P}$ \\
\hline Elevation & -0.265 & 1 & 10.25 & 0.013 \\
Soil pH & -35.85 & 1 & 6.54 & 0.034 \\
Soil nitrogen content & -64.87 & 1 & 9.56 & 0.015 \\
Soil water content & 0.608 & 1 & 9.21 & 0.016 \\
Aspect & & 7 & 4.57 & \\
North & 20.593 & & & 0.024 \\
East & -22.66 & & & 0.021 \\
Error & & 8 & & \\
\hline
\end{tabular}

Note: $\mathrm{R}^{2}=0.83$. Beta $(\mathrm{B})$, degree of freedom $(\mathrm{df})$, F statistics and $P$ values are given

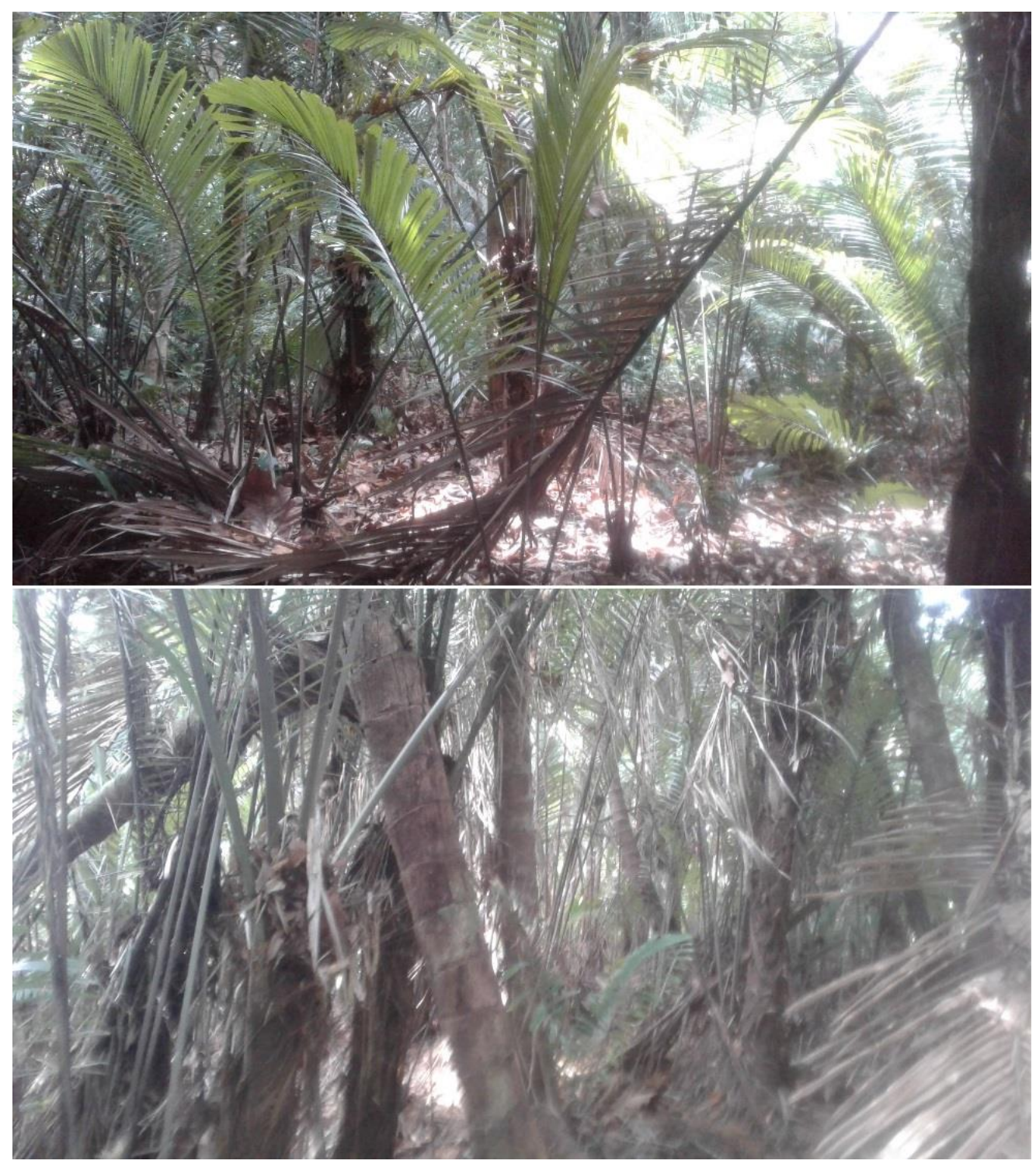

Figure 5. Population of dominant tree langkap (Arenga obtusifolia) in surrounding areas of Mount Payung, Ujung Kulon National Park, Banten, Indonesia 


\section{Habitat disturbance and conservation status}

Direct threat to kokoleceran population due to human activities was not found during the survey. However, the invasive langkap tree (A. obtusifolia) was observed to be widely distributed at the surrounding areas of Mount Payung (Figure 5). Known as generalist species (Robiansyah and Davy 2015) and to have very fast growth rate and reproduction ability (Muntasib and Haryanto 1992), langkap could invade the habitat of kokoleceran in the near future. Schenkel et al. (1978) reported that the canopy of langkap is very dense so that less than $5 \%$ of the light reaches the forest floor. This leads to the absent or very low density of seedlings and saplings of other plant species in langkap-dominated areas (Prayitno 1995).

GeoCAT estimated that both AOO and EOO of kokoleceran were $8 \mathrm{~km}^{2}$. As this species exists at only one single location, has small population size and is projected to experience decline in quality of habitat due to langkap invasion, under the IUCN Red List Categories and Criteria (IUCN 2012) kokoleceran meets the category for Critically Endangered B1ab(iii,v) +2ab(iii,v); C2a(ii). This category indicates a higher threat than of Endangered A1c; D assigned by Ashton (1998) more than 20 years ago. Thus immediate and comprehensive conservation actions are needed in order to conserve and protect kokoleceran and its habitat.

\section{Conservation implications}

Based on our results, the priority conservation actions for kokoleceran should include at least four aspects: i) to maintain the protection level of UKNP, especially forest areas of Mount Payung, ii) to reduce the impact of langkap as the main threat to the species, iii) to create new population of kokoleceran in other areas of the park through reintroduction program, and iv) to develop ex-situ conservation of the species by means of seed bank and living collection at botanic gardens and other ex-situ conservation areas.

Protection of kokoleceran habitat in Mount Payung was considered adequate since no anthropogenic threats found during the survey. To maintain this desired situation, regular patrol by the officer of UKNP is required. For the control management of langkap, the management of UKNP, in fact, had been controlling the distribution of this species to restore the habitat and feeding ground of Javan Rhinoceros. Both chemical and manual clearance method had been used to control the palm (Hariyadi et al. 2012; Inov 2013). While manual clearance involving cutting and removing trunk, fond and fruit, the chemical technique used glyphosate isoprophylammonium@Roundup which was injected into the palm trunk (Inov 2013). Inov (2013) argued that, compared to the manual one, the chemical clearance resulted in more rapid palm mortality, produces no detectable negative environmental impacts, and is no more expensive than cutting. This method, therefore, could also be applied for controlling the palm at kokoleceran habitats.

Reintroduction of kokoleceran had been conducted by Bogor Botanic Gardens (BBG) at Javan Rhino Study and Conservation Area (JRSCA) in 2014. During the monitoring conducted in 2017, however, none of the transplants could be located (Robiansyah and Dodo 2018). Robiansyah and Dodo (2018) suggested that for successful effort of reintroduction, it should consider strict site selection process and local people involvement. Concerning ex-situ conservation of kokoleceran, there are currently four living collections of kokoleceran at BBG, whereas none of its seed has been collected at the seed bank of BBG and other seed banks in Indonesia. Thus further collection of seeds and seedling of kokoleceran is needed to add the number of seeds and living collections at BBG and other ex-situ conservation sites.

\section{ACKNOWLEDGEMENTS}

We would like to thank Ujung Kulon National Park for the research permit. We also would like to thank David Gill for his valuable comments on the manuscript. This work was undertaken with the grant support from the Global Tree Campaign (www.globaltrees.org).

\section{REFERENCES}

Ashton P. 1998. Vatica bantamensis. The IUCN Red List of Threatened Species 1998: e.T31319A9625224. DOI: 10.2305/IUCN.UK.1998.RLTS.T31319A9625224.en.

Ashton PS. 1982. Dipterocarpaceae. In: Flora Malesiana ser. I, vol. 9(2): 237-552.

Ashton PS. 1969. Speciation among tropical forest trees: some deductions in the light of recent evidence. Biol J Linn Soc 1:155-196.

Bachman S, Moat J. 2012. GeoCAT - an open source tool for rapid Red List assessments. BGCI Vol 9, No 1.

Bunyavejchewin S, LaFrankie JV, Baker PJ, Kanzaki M, Ashton PS, Yamakura T. 2003. Spatial distribution patterns of the dominant canopy dipterocarp species in a seasonal dry evergreen forest in western Thailand. For Ecol Manag 175:87-101.

Clarbrough ML (ed.). 1999. Ujung Kulon National Park Handbook. Directorate General of Forest Protection and Nature Conservation \& Ministry of Foreign Affairs and Trade and Department of Conservation, Jakarta.

Condit R, Ashton PS, Baker PJ, Bunyavejchewin S, Gunatilleke S, Gunatilleke N, Hubbell SP, Foster RB, Itoh A, LaFrankie JV, Hua Seng Lee, Losos E, Manokoran N, Sukumar R, Yamakura T. 2000. Spatial patterns in the distribution of tropical tree species. Science 288:1414-1418

Dephut (Departemen Kehutanan Republik Indonesia). 2007. 50 Taman Nasional di Indonesia. Sub Direktorat Informasi Konservasi Alam dan Lestari Hutan Indonesia, Bogor. [Indonesian]

Evnike MF. 2013. Pengaruh Pengendalian Langkap (Arenga obtusifolia) Terhadap Komposisi Tumbuhan Pakan Badak Jawa (Rhinoceros sondaicus). [Dissertation]. Departemen Konservasi Sumberdaya Hutan dan Ekowisata, Institut Pertanian Bogor, Bogor. [Indonesian]

Fangliang H, Legendre P, LaFrankie JV. 1997. Distribution patterns of tree species in a Malaysian tropical rain forest. J Veg Sci 8:105-114.

FFI. 2018. Indonesia: a global biodiversity hotspot. Flora \& Fauna International, Jakarta.

Fox JED. 1973. Dipterocarp seedling behavior in Sabah. Malays For 36: 205-214.

Ghazoul J. 2016. Dipterocarp Biology, Ecology, and Conservation. Oxford University Press, UK.

Grubb PJ, Turner IM, Burslem DFRP. 1994. Mineral nutrient status of coastal hill dipterocarp forest and adinandra belukar in Singapore: analysis of soil, leaves and litter. J Trop Ecol 10:559-577.

Hariyadi AR, Priambudi A, Setiawan R, Purnama H, Yayus A. 2012. Optimizing the habitat of the Javan rhinoceros (Rhinoceros sondaicus) in Ujung Kulon National Park by reducing the invasive palm Arenga obtusifolia. Pachyderm 52: 49-54. 
Haryanto. 1999. Ekologi langkap (Arenga obtusifolia) dan peranannya dalam degradasi habitat badak jawa (Rhinoceros sondaicus) di Taman Nasional Ujung Kulon. Laporan Riset Terpadu IV(1996-1998). Fakultas Kehutanan, Institut Pertanian Bogor, Bogor. [Indonesian]

Hommel PWFM. 1987. Landscape Ecology of Ujung Kulon (West Java, Indonesia). Soil Research Institute, Wageningen.

Hubbell SP. 1979. Tree dispersion, abundance, and diversity in a tropical dry forest. Science 203 (4387):1299-1309.

Inov S. 2013. Control of Invasive Arenga Palm (Arenga obtusifolia) in Habitat Suitable for Javan Rhino (Rhinoceros sondaicus) in Ujung Kulon National Park. Proceeding of 2003 International Elephant and Rhino Conservation \& Research Symposium. International Elephan Foundation, Azle, Texas.

IUCN. 2012. IUCN Red List Categories and Criteria: Version 3.1. Second edition. IUCN. Gland, Switzerland and Cambridge.

Janzen DH. 1974. Tropical blackwater ivers, animals, and mast fruiting by the Dipterocarpaceae. Biotropica 6(2): 69-103.

Kalima T, Wardani W. 2017. Vatica bantamensis. In: Yulita KS, Partomihardjo T, Wardani W (eds.). Prekursor Buku Daftar Merah Indonesia 1: 50 Jenis Pohon Kayu Komersial. Indonesian Plant Red List Authority, Bidang Botani, Pusat Penelitian Biologi-LIPI Cibinong Science Center, Bogor. [Indonesian]

Lemmens LHMJ, Soerianegara I, Keating WG, Wong WC, Ilic J. 2017. Vatica. In: Soerianegara I, Lemmens RHMJ (eds.). Plant Resources of South-East Asia No 5(1): Timber Trees; Major Commercial Timbers. PROSEA Foundation, Bogor, Indonesia.

Muntasib EKS, Haryanto. 1992. Pilot Project Pengelolaan Habitat Badak Jawa (Rhinoceros sundaicus): Hasil-hasil yang telah Dicapai dan Rencana Penelitian Berikutnya. Jurusan Konservasi Sumberdaya Hutan, Fakultas Kehutanan IPB. Bogor. [Indonesian]

Prayitno W. 1995. Pengaruh Pembukaan Langkap (Arenga obtusifolia) Terhadap Peningkatan Keanekaragaman Vegetasi dan Pertumbuhan
Tumbuhan Pakan Badak Jawa (Rhinoceros sondaicus Desm.) Di Plot Percontohan Cijengkol, Taman Nasional Ujung Kulon. [Dissertation]. Jurusan Konservasi Sumberdaya Hutan, Fakultas Kehutanan IPB. Bogor. [Indonesian]

Rahman DA, Gonzalez G, Haryono M, Muhtarom A, Firdaus AY, Aulagnier S. 2017. Factors affecting seasonal habitat use, and predicted range of two tropical deer in Indonesian rainforest. Acta Oecol 82: 41-51

Richards PW. 1996. The Tropical Rain Forest, 2nd Edition. Cambridge University Press, Cambridge.

Robiansyah I, Davy AJ. 2015. Population Status and Habitat Preferences of Critically Endangered Dipterocarpus littoralis in West Nusakambangan, Indonesia. Makara J Sci 19(4):150-160.

Robiansyah I, Dodo. 2018. Reintroduction of Indonesian Threatened Plants by Bogor Botanic Gardens: Lessons Learned from Ujung Kulon National Park. In preparation

Schenkel R, Schenkel-Hulligerand L, Ramono WS. 1978. Area Management for The Javan Rhinoceros (Rhinoceros sondaicus Desm.): A Pilot Study. Malay Nat J 31:253-275.

Smits WTM. 1982. Dipterocarpaceae, vegetative propagation and mycorrhiza. M.Sc. thesis. Wageningen. 93 pp

Turner BL. 2012. Soil Classification in the 2 ha Forest Dynamics Plot in the Primary Forest, Bukit Timah Nature Reserve, Singapore. Smithsonian, Washington DC.

Widjaja EA, Rahayuningsih Y, Rahajoe JR, Ubaidillah R, Walujo EB, Semiadi G. 2014. Kekinian Keanekaragaman Hayati Indonesia 2014. LIPI Press, Jakarta. [Indonesian]

Wihermanto, Dodo, Kusuma, YWC, Muhiban. 2015. Autekologi Kokoleceran (Vatica bantamensis) di Taman Nasional Ujung Kulon. Prosiding Ekspose dan Seminar Pembangunan Kebun Raya Daerah, 161-170. [Indonesian] 